\section{Two:One Atrioventricular Block in Infants with Congenital Long QT Syndrome}

\author{
WILLIAM A. SCOTT, MD \\ MACDONALD DICK H, MD
}

C ongenital prolongation of the QT interval is a rare but life-threatening disorder of the cardiac conduction system..$^{1-5}$ The disorder usually presents as syncope or sudden death due to complex polymorphic ventricular tachycardia (torsade de pointes) or ventricular fibrillation. ${ }^{6}$ The major hypothesis explaining the disorder is an imbalance of sympathetic discharge between the right and left stellate ganglia resulting in inhomogeneity of ventricular refractoriness and a substrate for reentrant ventricular arrhythmias. ${ }^{4-6}$ Although sinus bradycardia may be associated with the syndrome, abnormalities in atrioventricular (AV) conduction are rare. ${ }^{4}$ In this report we present 3 infants with the congenital long QT syndrome and 2:1 AV block and provide support for the role of the long effective refractory period in producing the block.

The clinical and electrocardiographic data and electrocardiograms of the 3 patients are shown in $\mathrm{Ta}$ ble I and Figure 1. Patient 1 presented at birth with sustained but intermittent ventricular tachycardia. At 24 hours of age, the infant was noted to exhibit 2:1 AV block. An isoproterenol infusion decreased the $Q T_{c}$ to 0.44 second, resulting in the return of $1: 1 \mathrm{AV}$ conduction; however, it also increased the frequency of the ventricular arrhythmia. A pacemaker was implanted as isoproterenol was withdrawn. She was followed

From the Division of Pediatric Cardiology, C. S. Mott Children's Hospital, and The Department of Pediatrics, University of Michigan, Ann Arbor, Michigan 48109. Manuscript received June 4, 1987; revised manuscript received and accepted August $13,1987$. elsewhere and remained well until 2 years of age when she died suddenly.

Patient 2, who exhibited no tachyarrhythmias, received atropine on a trial basis; the $Q^{T} T_{C}$ shortened from 0.58 to 0.48 second and, because the sinus cycle length was longer ( 0.50 second], $1: 1 \mathrm{AV}$ conduction was possible. However, 2:1 AV block unresponsive to atropine reappeared at 5 weeks of age. A permanent pacemaker was implanted (and a patent ductus arteriosus ligated). Propranolol was initiated but was discontinued by the parents. He died suddenly at home at 3.8 years without any preceding episodes.

Patient 3 exhibited first-degree block (PR $0.26 \mathrm{sec}-$ ond) of the conducted beats as well as second-degree block (Figure 1C) without evidence of complete $A V$ dissociation (i.e., complete heart block) during long continuous recordings. She also presented with sustained intermittent polymorphic ventricular tachycardia. While awaiting permanent pacemaker implantation, the patient underwent ventricular programmed extrastimulation coupled to spontaneous or driven ventricular cycle lengths of 1,000 (spontaneous ventricular rate during 2:1 AV block], 600,500, 465 and $400 \mathrm{~ms}$ (Table II). The ventricular effective refractory period was reduced from $480 \mathrm{~ms}$ during a spontaneous ventricular cycle length of $1,000 \mathrm{~ms}$ to $230 \mathrm{~ms}$ pacing at a cycle length of $400 \mathrm{~ms}$.

All 3 pationts had normal hearing tosts; all 3 had age-appropriate speech development. There was no family history of the long QT syndrome. Electrocardiograms in the parents and siblings were normal. $\beta$ blocking therapy (propranolol 2 to $4 \mathrm{mg} / \mathrm{kg} /$ day in 4 divided doses) was recommended to all 3 patients but taken by patients 2 and 3 only. Permanent ventriculardemand pacemakers (VVI) were implanted to increase the ventricular rate (all patients) as well as overdrive to suppress the ventricular tachyarrhythmia (patients 2 and 3). The absolute QT interval decreased during permanent pacing at a mean rate of 110 beats/min from a mean of 0.65 to 0.46 second. As expected the $\mathrm{QT}_{c}$ remained unchanged at a mean of 0.62 second.

TABLE I Patients with Congenital Long QT Syndrome and 2:1 Atrioventricular Block

\begin{tabular}{|c|c|c|c|c|c|c|c|c|c|c|c|c|c|c|c|c|c|}
\hline \multirow[b]{3}{*}{$\mathrm{Pt}$} & \multirow[b]{3}{*}{ Sex } & \multirow[b]{3}{*}{ Arrh } & \multicolumn{6}{|c|}{ Initial } & \multicolumn{6}{|c|}{ Follow-Up } & \multirow{2}{*}{\multicolumn{2}{|c|}{ Treatment }} & \multirow[b]{3}{*}{ Status } \\
\hline & & & \multirow{2}{*}{$\begin{array}{c}\text { Age } \\
\text { (Onset } \\
\text { Block) }\end{array}$} & \multirow{2}{*}{$\begin{array}{l}\text { Sinus } \\
\text { Cycle } \\
\text { Length } \\
\text { (s) }\end{array}$} & \multirow{2}{*}{$\begin{array}{l}\text { Sinus } \\
\text { Rate } \\
\text { (bpm) }\end{array}$} & \multirow{2}{*}{$\begin{array}{l}\text { Vent } \\
\text { Rate } \\
\text { (bpm) }\end{array}$} & \multirow[b]{2}{*}{$\begin{array}{l}\text { QT } \\
(s)\end{array}$} & \multirow[b]{2}{*}{$\begin{array}{l}\text { QTc } \\
\text { (s) }\end{array}$} & \multirow[b]{2}{*}{$\begin{array}{l}\text { Age } \\
(y r)\end{array}$} & \multirow{2}{*}{$\begin{array}{l}\text { Sinus } \\
\text { Cycle } \\
\text { Length } \\
\text { (s) }\end{array}$} & \multirow[b]{2}{*}{$\begin{array}{l}\text { Sinus } \\
\text { Rate }\end{array}$} & \multirow[b]{2}{*}{$\begin{array}{l}\text { Vent } \\
\text { Rate }\end{array}$} & \multirow[b]{2}{*}{$\begin{array}{l}\text { QT } \\
\text { (s) }\end{array}$} & \multirow{2}{*}{$\begin{array}{l}\text { QTc } \\
\text { (s) }\end{array}$} & & & \\
\hline & & & & & & & & & & & & & & & Short-Term & Long-Term & \\
\hline 1 & $F$ & PVT & Birth & 0.72 & 81 & 42 & 0.72 & 0.62 & - & - & - & - & - & - & $\begin{array}{l}\text { Isoproterenol } \\
\text { Temporary PM }\end{array}$ & $\begin{array}{l}\text { VVI PM } \\
\text { Propranolol* }\end{array}$ & $\begin{array}{r}\text { Dead, } 2 \\
\text { years }\end{array}$ \\
\hline 2 & $M$ & 0 & 2 days & 0.38 & 158 & 79 & 0.56 & 0.64 & 3.8 & 0.8 & 75 & 75 & 0.52 & 0.58 & Atropine & $\begin{array}{l}\text { VVI PM } \\
\text { Propranolol }^{\dagger}\end{array}$ & $\begin{array}{c}\text { Dead, } 3.8 \\
\text { years }\end{array}$ \\
\hline 3 & $F$ & PVT & Birth & 0.52 & 115 & 58 & 0.68 & 0.67 & 1.5 & 0.6 & 100 & 100 & 0.38 & 0.5 & Temporary PM & $\begin{array}{l}\text { VV! PM } \\
\text { Propranolol }\end{array}$ & $\begin{array}{c}\text { Alive, } 1.5 \\
\text { years }\end{array}$ \\
\hline Mean & & & & 0.54 & 119 & 60 & 0.65 & 0.64 & & & & & & & & & \\
\hline
\end{tabular}

* Initial treatment but follow-up was elsewhere.

† Initial treatment but discontinued 2 years before first (and fatal) episode.

Arrh = arrhythmia; $\mathrm{bpm}=$ beats $/ \mathrm{min} ; \mathrm{PM}=$ pacemaker; PVT = polymorphic ventricular tachycardia (torsade de pointes); $\mathrm{QTC}=$ corrected $\mathrm{QT}$ interval; $\mathrm{VVI}=$ ventricular demand pacemaker. 
TABLE II Pacing Cycle Length Versus Ventricular Effective Refractory Period (VERP)

\begin{tabular}{cc}
\hline Cycle Length (ms) & VERP (ms) \\
\hline $1,000^{*}$ & 480 \\
600 & 350 \\
500 & 330 \\
465 & 310 \\
400 & 280 \\
\hline
\end{tabular}

* Spontaneous cycle length.

This report documents 2:1 AV block in 3 infants with congenital long QT syndrome and provides support that the mechanism of the 2:1 AV block is rclated to ventricular refractoriness relative to the sinus cycle length. Sinus impulses with short cycle lengths are blocked because the long ventricular effective refractory period is dependent on the previous long ventricular, not the shorter sinus, cycle length. Ventricular programmed extrastimulation in patient 3 (Table II) illustrates the marked dependency of the ventricular effective refractory period to the preceding ventricular cycle length in infants with the long QT syndrome. An associated factor in the mechanism of AV block in patients with the long QT syndrome may be the agerelated heart rate. Our patients were newborn infants with short resting cycle lengths and thus more likely to exhibit block in the presence of a long ventricular effective refractory period; with increasing age, the heart rates of 2 patients ( 1 and 3) slowed and 1:1 AV conduction appeared (Table I).

The experience in these 3 patients demonstrates that the very long rate-dependent ventricular effective refractory period and the age-related heart rate very likely contribute to the development of $2: 1 \mathrm{AV}$ block in infants with the congenital long QT syndrome. Further, it provides several new, practical clinical observations. Because the ventricular bradycardia such as occurs with heart block in the presence of a long QT interval increases the ventricular vulnerable period, the chance of induction of ventricular tachycardia or fibrillation by a ventricular premature beat is also increased. Overdrive pacing appears to reduce this risk in the newborn, perhaps by decreasing the inhomo-
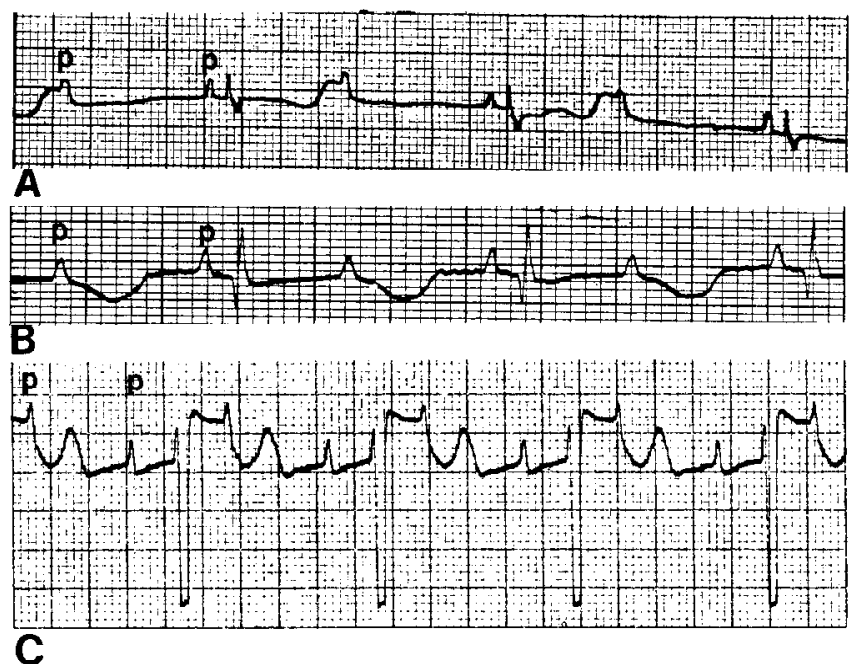

FIGURE 1. Representative electrocardiograms from patients $1(A)$, $2(B)$ and $3(C)$ demonstrating 2:1 atrioventricular block. Patient 3 has, in addition, first-degree block with a PR interval of $260 \mathrm{~ms}$. The paper speed in $A$ and $C$ is $25 \mathrm{~mm} / \mathrm{s}$ and in $B, 50 \mathrm{~mm} / \mathrm{s}$. $P=P$ wave.

geneity of refractoriness. Thus, permanent pacemaker implantation was indicated not only to manage the bradycardia, but also to reduce the chance of complex ventricular arrhythmias, possibly improving early survival of infants with these 2 findings. However, the 2 late deaths underscore the high mortality in this disorder as well as the importance of $\beta$ blockade. Finally, the combination of ventricular tachyarrhythmias and heart block in an infant strongly suggests the diagnosis of congenital long QT syndrome.

1. Jervell A, Lange-Nielsen F. Congenital deaf-mutism, functional heart disease with prolongation of the QT interval and sudden death. Am Heart J 1957;54:59-68.

2. Romano C, Gemme G, Pongiglione R. Aritmie cardiache rare dell'eta pediatrica. Clin Pediatr (Bologna) 1963;45:658-683.

3. Ward OC. New familial cardiac syndrome in children. I I rish Med Assoc 1964;54:103-106.

4. Scliwartz PJ, Periti M, Malliana A. The long QT syndrome. Am Heart Y $1975 ; 89: 378-390$

5. Bhandari AK, Scheinmann M. The long QT syndrome. Mod Concepts Cardiovase Dis 1985;54:45-50.

6. Moss AJ, Schwartz PJ. Delayed repolarization (QT or QTU prolongation) and malignant ventricular arrhythmias. Mod Concepts Cardiovass Dis 1982:51:85-90. 